\title{
Diarrhoea in north Karnataka: Rotavirus versus non-rotavirus
}

\author{
*Shankar Gouda V Patil', Bhavana Bhushan Lakhkar², S S Kalyanshettr ${ }^{2}$
}

Sri Lanka Journal of Child Health, 2018; 47: 204-209

\begin{abstract}
Background: As children with diarrhoea are often prescribed antibiotics, it was decided to study the causative organisms. Rotavirus is a major cause of diarrhoea and diarrhoea related mortality in most parts of India. Rotavirus vaccine is available but expensive. According to the World Health Organisation (WHO) the vaccine should be used in areas where diarrhoea related under five mortality is around $10 \%$. The situation in north Karnataka is not known.
\end{abstract}

Objectives: To find proportions of rotavirus and nonrotavirus diarrhoea in children of north Karnataka and study the key clinical features of rotavirus diarrhoea.

Study design and settings: Prospective observational study conducted in patients from the paediatric ward and outpatient department in a tertiary care hospital.

Method: Children 1 to 36 months old, presenting with acute diarrhoea from July 2014 to May 2016 and fulfilling selection criteria were included. Demographic and clinical details were noted. Stools were collected within 24 hours and subjected to routine and microscopic examination, test for presence of reducing substance, bacterial culture and Rapid ELISA test for rotavirus using antigen detection micro-well ELISA kit by Premere Rotaclone.

Results: A total of 168 children was recruited. Children positive for rotavirus ELISA were labelled as having rotavirus diarrhoea and comprised $52(31 \%)$ of total, including 17 with mixed infection and $15 \%$ were bacterial culture positive. Most common age group affected was 7 to 18 months (79\%). Male female ratio was same in rotavirus and non-rotavirus diarrhoea.

\footnotetext{
${ }^{1}$ Professor and Head of Department of Paediatrics, ${ }^{2}$ Professor, Paediatrics, Shri BM Patil Medical College, Vijayapur, India

*Correspondence: svpdr@yahoo.com (Received on 26 July 2017: Accepted after revision on 18 August 2017)

The authors declare that there are no conflicts of interest

Personal funding was used for the project.

Open Access Article published under the Creative

Commons Attribution CC-BY (c) (i)
}

The clinical features defining rotavirus diarrhoea were fever, vomiting, watery stools, respiratory symptoms and perianal excoriations. Moderate and severe dehydration were common. There was no mortality.

Conclusions: Around one third (31\%) of diarrhoea cases were positive for rotavirus and $15 \%$ were of only bacterial aetiology. Key clinical features in rotavirus infection were fever, vomiting, watery stools, respiratory symptoms and perianal excoriations.

DOI: http://dx.doi.org/10.4038/sljch.v47i3.8539

(Key words: Viral diarrhoea, rotavirus vaccine, prevalence)

\section{Introduction}

The proportion of rotavirus as a cause of death among causes of diarrhoea in children ranges in different states of India from 7\% in Vellore to $50 \%$ in Manipur ${ }^{1}$. According to the World Health Organisation (WHO), the under-five mortality has come down from 528,000 in 2000 to 215,000 in 2013 but $22 \%$ of global rotaviral deaths occurred in India ${ }^{2}$. The prevalence of rotavirus among all diarrhoeal causes has not been studied in Karnataka after 2002, to the best of our knowledge. Some anecdotal studies have reported $19.5 \%$ to $28 \%$ prevalence in south Karnataka ${ }^{3,4}$. Prevalence in North Karnataka has not been reported.

\section{Objectives}

To find the proportion of rotavirus and non-rotavirus diarrhoea in children of north Karnataka and to study the key clinical features of rotavirus diarrhoea.

\section{Method}

A prospective, observational study was conducted from July 2014 to May 2016 in the Department of Paediatrics, Shri BM Patil Medical College and Research Centre, Vijayapur Karnataka, India. Children between 1 to 36 months of age clinically diagnosed as acute diarrhoea ${ }^{5}$, and whose parents' consent could be obtained, were included. As per sample size calculation based on rotavirus prevalence in India ${ }^{6}, 168$ children were recruited from ward and outpatient department (OPD). Confidence interval at $7.5 \%$ margin of error was $95 \%$. Children immunized with rotavirus vaccine, had immunodeficiency disease or where parents denied consent were excluded. 
Ethical approval was obtained from institutional ethical committee of BLDE University Vijayapur.

Demographic information, feeding details, clinical presentation, complications, past significant history especially of diarrhoea, and anthropometry details were entered in a pre-validated, pretested proforma. Pre-validation and testing were done in 20 cases where proformas were filled and analysed for any deficiency of information. Then the format used in study was finalized. This finalized proforma was also validated by an external expert. Faecal samples were collected within 24 hours and were subjected to routine, microscopic examination, test for reducing substance, bacterial culture and rapid ELISA test for rotavirus using antigen detection micro-well ELISA kit by Premere Rotaclone. This kit qualitatively determines the rotavirus antigen in stool samples. As this kit was newly introduced in the hospital, around 200 investigations (Elisa Kit and stool culture) were made free for research. The sensitivity of this kit is $76.8 \%$ and specificity $100 \%$ when reverse transcriptase -PCR (RT-PCR) was used as the gold standard ${ }^{7}$.

Diagnosis of rotavirus diarrhoea was made if rotavirus ELISA was positive. If bacterial culture and rotavirus ELISA were both positive it was labeled as mixed infection. If only bacterial culture was positive, it was considered as bacterial diarrhoea. Dehydration was assessed and classified as mild, moderate and severe ${ }^{8}$.

Statistical analysis: All characteristics were summarized descriptively. For categorical data, number and percentage were used in data summaries. Chi-square $\left(\chi^{2}\right)$ / Freeman-Halton Fisher exact test was employed to determine the significance of differences between groups for categorical data. If the $p$-value was $<0.05$, results were considered to be significant. Data were analysed using SPSS software version 23.0.

\section{Results}

A total of 168 patients were recruited. Patient characteristics are presented in Table 1.

A history of loose stools was present in $168(100 \%)$ patients, vomiting in 137 (81\%), fever in $164(98 \%)$, perianal excoriation in $28(17 \%)$ and cold and cough indicating upper respiratory infection in $47(28 \%)$ patients. Dehydration was present in all (100\%) patients and was moderate in $94(56 \%)$ patients, severe in $35(20.8 \%)$ and mild in $39(23 \%)$ patients.

A total of $52(31 \%)$ were rotavirus ELISA test positive. Of these 17 (10\% of total) also had positive culture for bacteria and were categorized as mixed infection. Common associations were with
Escherichia coli (12 cases), Klebsiella (4 cases) and Proteus (1 case). In 25 (15\%) cases stool culture was positive only for bacteria, Escherichia coli and Klebsiella being more common.

Table 1: Patient characteristics $(n=168)$

\begin{tabular}{|l|c|}
\hline \multicolumn{1}{|c|}{ Patient characteristic } & Number (\%) \\
\hline Age (months) & $71(42.1)$ \\
$1-12$ & $49(28.9)$ \\
$13-24$ & $48(28.5)$ \\
$25-36$ & \\
\hline Sex & $99(58.9)$ \\
Male & $69(41.1)$ \\
Female & \\
\hline Nutritional status & $111(66.1)$ \\
Normal & $36(21.4)$ \\
Grade 1 & $19(11.3)$ \\
Grade II & $02(01.2)$ \\
Grade III+IV & \\
\hline Feeding pattern & $32(19.0)$ \\
Exclusive breastfeeding & $08(05.0)^{*}$ \\
Top feed only & $86(51.0)$ \\
Supplementary feed & $42(25.0)$ \\
Family diet & \\
\hline
\end{tabular}

* Top fed children received other milk only

Risk factors, clinical features, investigations and complications were compared in rotavirus and nonrotavirus diarrhoea (Table 2). The most common age group affected by rotavirus was 7 to 18 months. Rotavirus infection was uncommon below 7 months and above 24 months. The 17 cases with mixed infection also showed a similar distribution of age groups. In rotavirus negative diarrhoea, though the most affected age group was the same, children below 7 months and above 2 years were substantially affected. Sex ratio was not significantly different and there was no mortality in either group.

Mean duration of diarrhoea at the time of admission in rotavirus positive children was $2 \pm 1$ days in children with mild dehydration and $3 \pm 1$ days in children with moderate dehydration. There were only 8 children with grade II and III malnutrition in the rotavirus positive group, of whom 2 had mild and 6 had severe dehydration. There was no difference between malnourished children and normal children as far as dehydration is concerned $(p>0.05)$ in rotavirus group.

Correlation of type of feeding and rotavirus positivity is shown in Figure 1. Minimum prevalence of rotavirus infection was in the exclusively breast fed group. Significant correlation was found between nutritional status and prevalence of rotavirus diarrhoea (Odds ratio $=3.1$ at $95 \% \mathrm{CI}$ ). 
Table 2: Comparison of rotaviral and non-rotaviral diarrhoea

\begin{tabular}{|l|c|c|c|}
\hline \multicolumn{1}{|c|}{ Feature } & Rotavirus positive (n=52)* & Rotavirus negative (n=116) & P value \\
\hline Age groups (months) & $03(06 \%)$ & $18(16 \%)$ & \\
$1-6$ & $25(48 \%)$ & $25(22 \%)$ & $0.0025(\mathrm{~S})$ \\
$7-12$ & $16(31 \%)$ & $32(27 \%)$ & $01(0.9 \%)$ \\
$13-18$ & $06(11 \%)$ & $40(34 \%)$ & $0.827(\mathrm{NS})$ \\
$19-24$ & $02(04 \%)$ & $1.4: 1$ & $0.016(\mathrm{~S})$ \\
$>24$ & $1.3: 1$ & $89(77 \%)$ & $0.95(\mathrm{NS})$ \\
\hline Sex (M:F) & $48(92 \%)$ & $114(98 \%)$ & $<0.05(\mathrm{~S})$ \\
\hline Clinical features & $52(100 \%)$ & $16(14 \%)$ & $<0.05(\mathrm{~S})$ \\
Vomiting & $31(60 \%)$ & $06(05 \%)$ & $0.003(\mathrm{~S})$ \\
Fever & $22(42 \%)$ & $34(29 \%)$ & $0.006(\mathrm{~S})$ \\
Upper respiratory infection & $05(09.6 \%)$ & $73(62 \%)$ & $0.000(\mathrm{~S})$ \\
Perianal excoriation & $21(40.0 \%)$ & $09(08 \%)$ & $0.362(\mathrm{NS})$ \\
\hline Dehydration & $26(50.0 \%)$ & $30(26 \%)$ & $0.018(\mathrm{~S})$ \\
Mild & $17(32 \%) *$ & $02(04 \%)$ & \\
Moderate & $05(10 \%)$ & & \\
Severe & $25(48 \%)$ & $86(74 \%)$ & $0.006(\mathrm{~S})$ \\
\hline Stool sample & $19(36 \%)$ & $17(15 \%)$ & \\
Pus cells & $07(13 \%)$ & $01(0.9 \%)$ & \\
Reducing substance present & $01(02 \%)$ & & \\
\hline Nutritional status & & & \\
Normal & & & \\
Grade I & & & \\
Grade II & & & \\
Grade III & & & \\
\hline
\end{tabular}

*17 cases had mixed infection

**15 cases had mixed infections

(S): Significant, (NS): Not significant

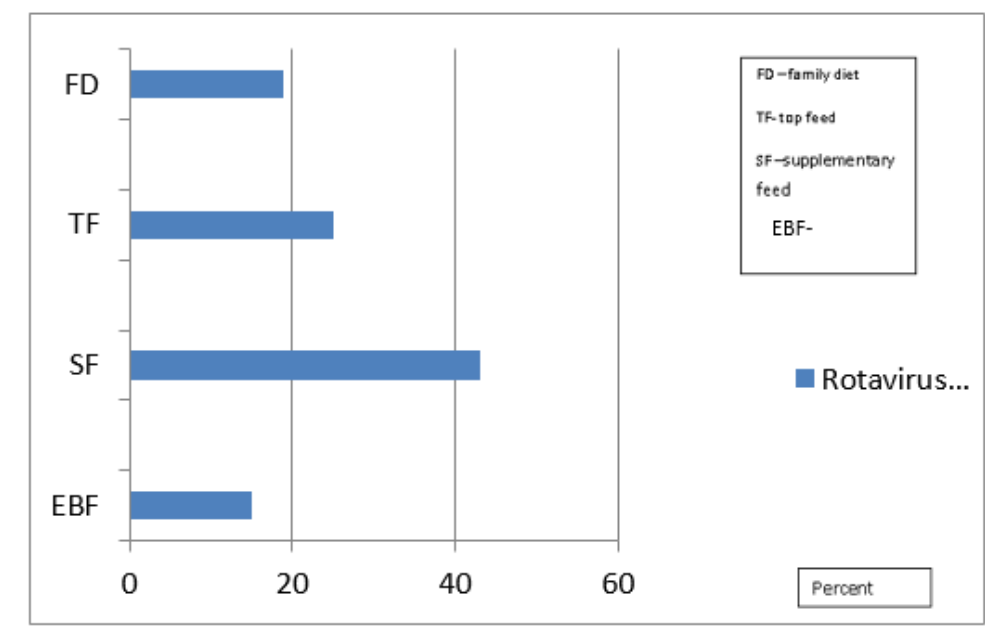

Figure 1: Correlation of type of feeding and rotavirus positivity

Stool samples in rotavirus positive children showed pus cells in 17 samples (32\%) of which 15 were mixed infections. Among the 25 bacterial culture positive children $18(72 \%)$ and among the 91 bacterial culture negative children 12 (19\%) showed pus cell in stools. In pure rotavirus infection only 2 samples showed pus cells. In the rotavirus group $10 \%$ (5 samples) and in non-rotavirus group 4\% (5 samples) showed presence of reducing substance $(\mathrm{p}<0.05)$. Thus, presence of reducing substances is significantly more in rotavirus diarrhoea. Mean duration of diarrhoea in rotavirus 
children with reducing substance was $4 \pm 3$ days, whereas in non-rotavirus diarrhoea it was $6 \pm 3$ days.

\section{Discussion}

WHO recommends inclusion of rotavirus vaccine in immunization programmes globally'. The present study gives some idea about the rotavirus burden in and around Vijayapur, north Karnataka, though community based studies are preferable. Community based studies are presently not available and data from the present study can be used keeping the limitations in mind. Moreover, prevalence of rotavirus diarrhoea in the community usually comes as low as most of these cases are in hospital due to severe dehydration ${ }^{10}$. Vijayapur has a mixed population from Karnataka and Maharashtra of around 2.2 million with mixed culture and religion, $76 \%$ hailing from rural areas. Though published data are not available, it is our observation from cases referred to this tertiary care hospital that most practitioners treat diarrhoeal episodes with antibiotics. The recognition of rotavirus aetiology clinically, might help in avoiding antibiotics.

Prevalence of rotavirus infections varies from country to country ${ }^{10-12}$ and in different states of India ${ }^{1}$. Prevalence varies in outpatient and inpatients settings of any hospital and in the community. In admitted patients it varies from 20 to $40 \%$ whilst in outpatient and in the community, median proportions are $16 \%$ and $15 \%$ respectively ${ }^{1}$. Our sample was from a mixed population of outpatients and inpatients and $31 \%$ of all diarrhoeal cases were positive for rotavirus which is similar to the above observation ${ }^{1}$. Age prevalence of 7 to 18 months, which we observed, has been described by other Indian studies ${ }^{13,14}$ and studies outside India $^{11,12}$, though an occasional study found more involvement below 6 months $^{11}$. Most studies ${ }^{10-13}$ including ours, found some male gender preponderance though this was statistically insignificant.

Fever was seen equally in both groups and this was also noted by others ${ }^{15}$. Contrary to popular belief, fever is not a significant feature of viral infections and is more common in non-rotavirus diarrhoea ${ }^{12}$. Vomiting was observed by us and by most authors ${ }^{12,16}$. Vomiting was probably responsible for the moderate and severe dehydration (60\% patients), common in rotavirus illness making oral intake impossible. This was also observed by other authors ${ }^{1,3,12,13,14,16}$. Respiratory symptoms were observed in $60 \%$ of our patients. Alkali et a ${ }^{17}$ and Surajuddin et a $l^{13}$ in Nigeria found respiratory symptoms in only $3-9 \%$ and $8 \%$ patients respectively which may be due to difference in strains in different geographical areas. Perianal excoriation due to secondary transient lactose intolerance was seen significantly more in rotavirus positive diarrhoea in the present study and is also described classically 5 .

As per 2008 estimates of global rotavirus linked mortality, $23 \%$ of all rotavirus deaths were in the Indian subcontinent ${ }^{17}$ and the main cause reported was severe dehydration. Rotavirus immunization programme planned by the Government of India may substantially reduce morbidity, cost of treatment and loss of working days for parents ${ }^{18}$.

Type of feeding was an important risk factor for rotavirus diarrhoea in the present study (Figure 1), children on supplementary feeding being at greatest risk followed by top fed children. Exclusive breast feeding offered some protection. Similar observations about breast feeding were made by other authors ${ }^{19}$. Nitiema et al did not find any significant difference between rotavirus or non-rotavirus infection in breast fed babies but $67 \%$ of rotavirus infected children were either non breastfed or on mixed feeding ${ }^{21}$. Many authors, similar to us, reported nutritional status as a risk factor for rotavirus diarrhoea ${ }^{21,22}$. In fact, Nitiema et al observed more severity of rotavirus and mixed infections diarrhoea in wasted children and increased duration in wasted and stunted children ${ }^{21}$.

Present study showed that in rotavirus positive children, presence of pus cells was not significantly different from non-rotavirus cases, but most rotavirus positive children with pus cells in stools had mixed infections. If these children with mixed infections are removed from the group then presence of pus cells was significantly more in non-rotavirus group. Sangkapali et $a l^{16}$ did not find any difference in stools of the two groups when tested for lactose intolerance. Present study showed significantly more children with reducing substance in stools in rotavirus diarrhoea $(10 \%$ vs $4 \%)$.

Around $10 \%$ of patients in the study had mixed infections, the commonest combination being rotavirus and E Coli. Bhavani et al studied diarrhoeal diseases in the community and found $21 \%$ had mixed infections ${ }^{23}$. Most common association observed by them was rotavirus, E coli as well as Giardia. They also observed increased severity of diarrhoea during co-infection like present study ${ }^{23}$. Bilenko et al had contradictory findings where co-infection did not change the severity ${ }^{24}$. This difference in the observations may be due to different geographical locations, socioeconomic and nutritional status of patients and virulence of organisms of different strains. The hospital based nature of the study is one of the main limitations. A larger sample size also 
would have been better. Most children with rotavirus diarrhoea needed hospital admission increasing cost of treatment. This indicates a definite need for the introduction of rotavirus vaccine to the immunization schedule in this area.

\section{Conclusions}

Around one third (31\%) of all diarrhoea cases in our study were positive for rotavirus and $15 \%$ were of only bacterial aetiology. Key clinical features in rotavirus infection were fever, vomiting, watery stools, respiratory symptoms and perianal excoriations.

\section{References}

1. Kahn G, Fitzwater S, Tate J, Kang G, Ganguly $\mathrm{N}$, Nair G et al. Epidemiology and prospects for prevention of rotavirus disease in India. Indian Pediatrics 2012; 49: 467-74.

https://doi.org/10.1007/s13312-012-0076-7

PMid: 22796685

2. WHO. Estimated rotavirus deaths for children under 5 years of age 2013:215000. Available from:

http://www.who.int/immunization/monitoring_su rveillance/burden/estimates/rotavirus/en/ (Accessed on 16/5/2017).

3. Shetty A K, Kalekhan F M, Muthiravalapil S J, Boloor R, Antony B. Detection of rotavirus and adenovirus diarrhoea in children below five years, in Dakshina Kannada District, a coastal region of Karnataka State, India. Muller Journal of Medical Sciences and Research 2014; 5(2); 143-8.

https://doi.org/10.4103/0975-9727.135749

4. Ballal M, Shivananda PG. Rotavirus and enteric pathogens in infantile diarrhoea in Manipal, South India. Indian Journal of Pediatrics 2002; 69:3936 .

https://doi.org/10.1007/BF02722628

PMid: 12061671

5. Bhutta ZA. Acute gastroenteritis in children, Chapter 332 In: Kliegman R M, Stanton BF, .Geme J W, Schor N F, Behrman R E editors. Nelson Textbook of Pediatrics, 19th ed. Elsevier Saunders Philadelphia; 2012.p1323-33.

6. Mathew MA, Abraham P, Chitralekha S, Nair MKC, Kang G, Kilgore P. Prevalence of rotavirus diarrhoea among hospitalized under-five children. Indian Pediatrics 2014; 51: 27-3 https://doi.org/10.1007/s13312-014-0329-8

PMid: 24277960

7. Gautam R, Lyde F, Esona MD, Quaye O, Bowen MD. Comparison of Premier ${ }^{\mathrm{TM}}$ Rotaclone $\AA$, ProSpecT ${ }^{\mathrm{TM}}$, and RIDASCREEN ${ }^{\circledR}$ rotavirus enzyme immunoassay kits for detection of rotavirus antigen in stool specimens. Journal of Clinical Virology 2013; 58(1):292-4.

https://doi.org/10.1016/j.jcv.2013.06.022

PMid: 23850415 PMCid: PMC4602374

8. Singhi S. Fluids, electrolytes and acid base disorders. In : Parthsarathi A, Menon S, Gupta P, Nair MKC (editors) IAP textbook of pediatrics.$^{6 \text { th }}$ ed. JAYPEE bros medical publishers 2013 pp 917-926.

9. WHO rotavirus vaccines position paper. Available from:

http://www.who.int/immunization/policy/positio n_papers/rotavirus/en/ (Accessed on 12/3/2017).

10. Ramani S, Kang G. Burden of disease \& molecular epidemiology of group A rotavirus infections in India. Indian Journal of Medical Research 2007; 125:619-32.

PMid: 17642497 PMCid: PMC2474761

11. Tinsa F, Brini I, Yahyaoui S, Bousenna O, Bousetta K, Bousnina S et al. Infectious diarrhoea in children under five years. Tunis Med. 2009; 87(9):599-602.

PMid: 20180381

12. De Villiers FP, Sawyerr TN, de Villiers GK. The incidence and clinical presentation of infantile rotavirus diarrhoea in Sierra Leone. African Medical Journal 2009; 99(4):249-52.

13. Surajudeen AJ, Chijioke U, Olabode AO, Band JM. Incidence of rotavirus infection in children with gastroenteritis attending Jos university teaching hospital. Virology Journal 2011; 8:233. https://doi.org/10.1186/1743-422X-8-233

PMid: 21575246 PMCid: PMC3107812

14. Gladstone B P, Ramani S, Mukhopadhya I, Jayaprakash M, Sarkar R, Rahman AM et al. Protective effect of natural rotavirus infection in an Indian Birth Cohort. New England Journal of Medicine 2011; 365:337-46. https://doi.org/10.1056/NEJMoa1006261 PMid: 21793745 PMCid: PMC3596855 
15. Bahl R , Ray P, Subodh P, Shambharkar S, Saxena P, Parasher U. Incidence of severe rotavirus diarrhoea in New Delhi India and G and $\mathrm{P}$ types of infective rotavirus strains. Journal of Infectious Disease 2005; 192: S114-9. https://doi.org/10.1086/431497

PMid: 16088794

16. Sungkapalee T, Puntukosit P, Eunsuwan O, Theamboonlers A, Chongasrisawat $\mathrm{V}$ et al. Incidence and clinical manifestations of rotavirus infection among children with acute diarrhea admitted at Buri ram hospital Thailand. Southeast Asian Journal of Tropical Medicine and Public Health 2006; 37(6):1125-31.

PMid: 17333764

17. Alkali BR, Daneji AI, Magaji AA, Bilbis LS. Symptoms of human rotavirus infection observed in children in Sokoto, Nigeria. Advances in Virology 2015; 2015; 2015:890957. https://doi.org/10.1155/2015/890957

18. Tate JE, Burton A H, Boschi-Pinto C, Steele AD, Duque J, Parasher UD .WHO coordinated Global rotavirus surveillance Network 2008 estimate of worldwide rotavirus associated mortality in children younger than 5 years before introduction of universal rotavirus vaccination program: a systematic review and meta-analysis. Lancet Infectious Disease 2012; 12(2):136-41. https://doi.org/10.1016/S1473-3099(11)70253-5

19. Achieving a new milestone towards expanding full immunization coverage in the country to reduce child mortality. Press information bureau, Government of India, Ministry of health and family welfare. 26.03.2016. Available as: http://pib.ic.in/newssite/printrel (Accessed on 12/06/2016).

20. John BM, Devgan A, Mitra B. Prevalence of rotavirus infection in children below two years presenting with diarrhoea. Medical Journal Armed Forces India 2014; 70(2):116-9. https://doi.org/10.1016/j.mjafi.2014.02.008

PMid: 24843198 PMCid: PMC4017201
21. Nitiema LW, Nordgren J, Quermi D, Dianou D, Traore AS, Svensson L et al. Burden of rotavirus and other entero-pathogens among children with diarrhoea in Burkina Faso. International Journal of Infectious Disease 2011; 15(9): e646-52. https://doi.org/10.1016/j.ijid.2011.05.009 PMid: 21763172

22. Shrivastava S, Awasthi S, Jain A, Verma S, Gupta S, Singh M. Rotavirus diarrhea in under five population in northern India. Indian Journal of Community Health 2015; 27(3):356-60.

23. Bhavani JE, Goldstick D, Cevallos W, Trueba G, Eisenberg JNS. Synergistic effects between Rotavirus and co-infecting pathogens on diarrheal diseases: Evidence from a community based study in Northwestern Ecuador. American Journal of Epidemiology 2012; 176(5): 387-95.

https://doi.org/10.1093/aje/kws220

PMid: 22842722 PMCid: PMC3499114

24. Bilenko N, Levy A, Dagan R, Deckelbaum R J ,Yossef El-On, Drora F et al . Does co-infection with Giardia Lamblia modulate the clinical characteristics of enteric infections in young children? European Journal of Epidemiology 2004; 19 (9):877-83. https://doi.org/10.1023/B:EJEP.0000040533.756 $46.9 \mathrm{c}$

PMid: 15499898 